\title{
Erratum to: Utopias of return: notes on (post-)Soviet culture and its frustrated (post-)modernisation
}

\author{
Evgeny Dobrenko
}

Published online: 17 June 2011

(C) Springer Science+Business Media B.V. 2011

\section{Erratum to: Stud East Eur Thought \\ DOI 10.1007/s11212-011-9142-2}

The translator of Evgeny Dobrenko's article Samantha Sherry is listed as affiliated with the University of Glasgow (bottom of p. 1 and meta-data) while it should read University of Edinburgh. Her affiliation should read:

\section{Samantha Sherry}

School of Literatures, Languages and Cultures

University of Edinburgh

George Square

Edinburgh EH8 9JX

Scotland 